\title{
New Insights in Citron (Citrus medica L.) Genomics and Fruit Development
}

\author{
Eliezer E. Goldschmidt ${ }^{1}$ \\ Institute of Plant Sciences and Genetics in Agriculture, The Robert H. Smith Faculty of Agriculture, Food \\ and Environment, The Hebrew University of Jerusalem, P.O. Box 12, Rehovot 76100, Israel
}

Additional index words. fingered citron, genomics, persistent style

\begin{abstract}
The citron (Citrus medica $\mathbf{L}$.) is one of the forefathers of the citrus tribe and was the first Citrus to reach the Mediterranean, according to Theophrastus' testimony (Tolkowsky, 1938). Citron's biology is inseparable from its cultural and traditional legacy, from the Classic period until now. The rapidly evolving molecular tools and the increasing availability of germplasm enable reconstruction of the genomic pathway of citrus evolution and speciation. The recent progress in citron genomics is reviewed, paying special attention to the fingered citron. Among the unique biological traits of citrons, the persistent style (Pitam) played a special role. The biology of style persistence and its regulation by the synthetic auxin, Picloram, are described. Analysis of Jewish scripts and archaeological evidence regarding the requirement of style persistence for the use of citrons in the Feast of Tabernacles does not provide an unequivocal answer. However, citrons with a persistent style have been in high preference in recent centuries' citron trade.
\end{abstract}

The citron (Citrus medica L.) is believed to be one of the ancestors of the citrus group (Barrett and Rhoads, 1976), but its study was somewhat neglected during the 20th century, presumably because of its limited commercial use. However, renewed interest in various aspects of the citron has arisen in recent years, concurrent with rapid development of molecular and genomic technologies, leading to a wealth of new information. The unique cultural, medical, and sacramental history of the citron has been reviewed from different angles (Isaac, 1959; Langgut, in press; Maruca et al., 2015; Nicolosi et al., 2005; Tolkowsky, 1938). The aim of the present report is to review areas of recent progress and address certain specific topics that have not received sufficient attention previously.

\section{Genomics of Citrus medica}

Whereas earlier citrus germplasm studies included a very small number of citron cultivars, recent studies examined larger numbers of citron accessions (starting with Barkley et al., 2006, - 29 citrons), thereby enabling a broader evaluation of the genetic

\footnotetext{
Received for publication 20 July 2016. Accepted for publication 17 Aug. 2016.

This article was presented as part of a workshop titled "Fresh Perspectives on Citrus History" during the ASHS Annual Conference, which was held on 4-7 August, 2015, in New Orleans, LA. The author thanks David Karp, the coordinator of this workshop, for advice and unfailing support throughout the preparation of the manuscript, Chandrica Ramadugu for thoughtful discussions, Rivka Ben-Sasson for invaluable help with the archaeological photos, Moshe Bar-Joseph for critical reading of the manuscript, Moshe Huberman for excellent technical assistance, and the editorial reviewers for refining the manuscript.

This article is published in honor of Jules Janick, world-renowned pomologist, fruit breeder, historian of horticulture, and prolific editor, wishing him continued fruitful creativity.

${ }^{1}$ Corresponding author. E-mail: eli.goldsmit@mail. huji.ac.il.
}

diversity within the citron clade. Furthermore, whereas earlier studies examined Mediterranean citrons (Nicolosi et al., 2000b, 2005), and very few non-Mediterranean accessions (Barkley et al., 2006; Luro et al., 2012), recent studies included numerous citron accessions from China (Ramadugu et al., 2015) and Tibet (Yang et al., 2015).

Citron's monoembryony and selfcompatibility have been recognized previously (Hodgson, 1967; Scora, 1975), but other traits became evident only recently. Of the citrus groups that are thought to be true Citrus species, citrons had the lowest observed heterozygosity, suggesting a high rate of selfing (Barkley et al., 2006). Luro et al. (2012) also noted that in Corsican citrons, male and female floral organs matured concomitantly before opening of the petals, indicating a self-fecundation mechanism. The fact that citron propagation by seed, still widely practiced in Israeli home gardens, seldom results in hybrid seedlings further supports this conclusion (Goldschmidt, 2009). This seems to imply that in the presumed evolution of citron hybrid species (e.g., lemon), citron generally served as the male parent (Curk et al., 2016; Ramadugu et al., 2015; Yang et al., 2015).

Among recent genetic citron analyses, the one performed by Ramadugu et al. (2015) is the most extensive so far, including 32 Chinese and 15 Mediterranean citrons. Yang et al. (2015) included citrons from Tibet in addition to the Chinese ones, but no Mediterranean citrons were considered in this study. Unfortunately, both studies did not include accessions from Northeast India, which could have shed further light on the citron evolution puzzle (Jena et al., 2009).

The genetic homozygosity and diversity of Citrus medica deserves further discussion. On one hand, citrons from most distant geographical origins bear distinct genomic similarities. Thus, all the citron accessions analyzed by Ramadugu et al. (2015) had a nuclear insertion of 146-175 bp that was missing in all noncitron accessions, and a 357-bp deletion was exclusively detected in chloroplast genomes of citrons (Carbonell-Caballero et al., 2015). And yet, on the other hand, the structural analysis of Ramadugu et al. (2015) identified three major populations: a Chinese nonfingered citron cluster, a Chinese fingered citron cluster, and a Mediterranean cluster (Fig. 1), indicating that the Mediterranean citrons did not originate in China. This seems to support the hypothesis that the origin of the Mediterranean citrons should be sought in Northeast India, in the vicinity of the indigenous Citrus indica (Jena et al., 2009).

The fingered citron (Citrus medica var. sarcodactylis), also known as "Buddha's Hand," is widespread in Yunnan and other southern provinces of China, with numerous cultivars (Karp and $\mathrm{Hu}$, in press). The fingered phenotype results from a unique developmental malformation, whereas in normal citrus fruit, the hesperidium berry consists of united, radially arranged carpels; in the fingered citron, the carpels develop as separate, elongated fingers, composed of flavedo and albedo, mostly devoid of seeds and juice sacs. There are, however, intermediate forms with partially united carpels (Fig. 2) and rudimentary juice sacs (Fig. 3). The basic molecular regulation of this developmental trait has yet to be discovered. Considerable genomic diversity among fingered citrons was found by Ramadugu et al. (2015), indicating that the different fingered forms may have evolved independently of each other (Karp and Hu, in press; Ramadugu et al., 2015). As mentioned above, Yang et al. (2015) examined accessions from Yunnan (China) and Tibet. In their population structure analysis, the fingered citrons turned out to be closer to the Tibet citrons than to those from Yunnan. This led them to hypothesize that the fingered citron might have evolved in parallel with the usual, nonfingered citron from a common ancestor (Yang et al., 2015). However, the fingered phenotype is only one 


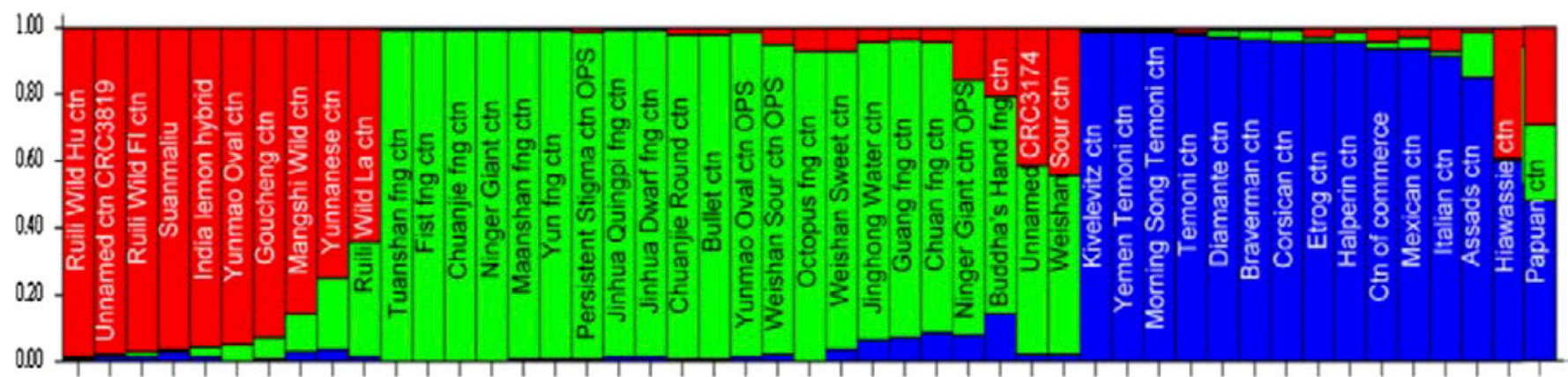

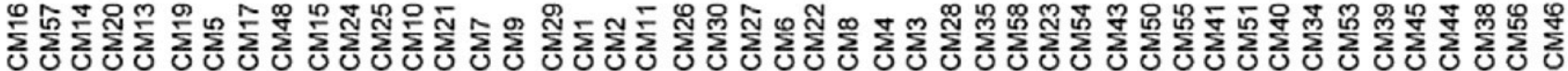

Fig. 1. Population structure analysis of citrons using data from 23 microsatellite markers. Three major populations were inferred. Y axis represents probable admixture in each accession. Cluster 1 (Red) primarily represents nonfingered wild citrons from China, including many likely hybrids. Cluster 2 (green) consists of fingered and some nonfingered citrons from China. Cluster 3 (blue) represents nonfingered citrons from many locations such as Israel, Italy, Morocco, and United States. (Ramadugu et al., 2015, by permission). ctn = citron; fng = fingered; OPS = open-pollinated seedling.

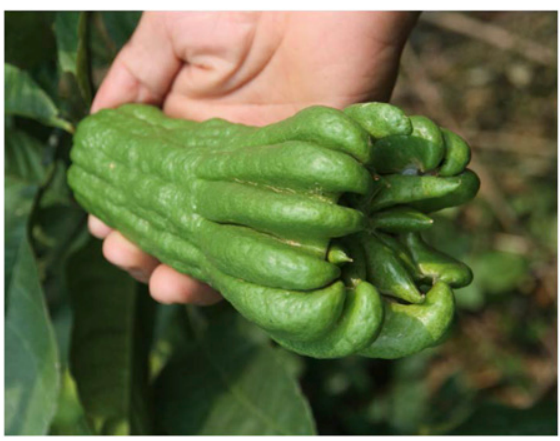

Fig. 2. Guang fingered citron; note the partially united carpels (photo by David Karp).

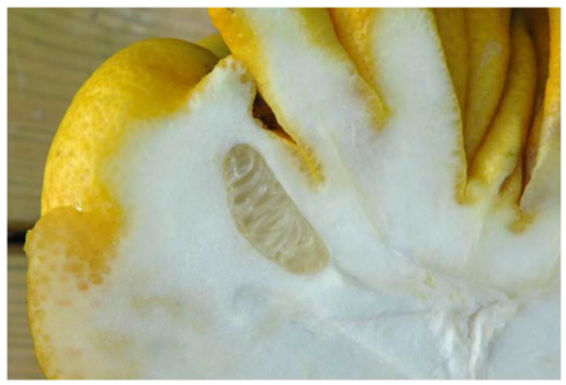

Fig. 3. A section of Yun fingered citron; note the presence of juice vesicles (photo by David Karp).

(although probably the most extreme) of numerous phenotypic variations within Citrus medica cultivars - differences in fruit shape (Goldschmidt, 1976), size, taste (sweet vs. acid-sour), and style persistence-all of which are not yet explicable in geneticphysiological terms.

\section{The Persistent Style—Pitam}

A whole citrus flower contains both stamens (=male organs) and pistil (=female organ); the ovary, style, and stigma comprise the pistil [Incidentally, the shape of the cylindrical style which expands into the flat-rounded stigma bears similarity to a pes-

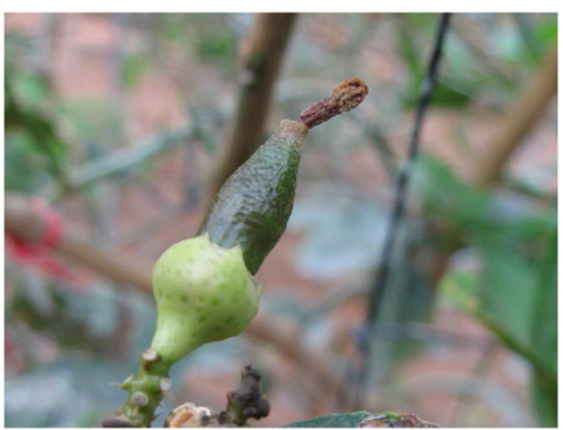

Fig. 4. A citron fruitlet (ca. $20 \mathrm{~d}$ after anthesis) undergoing style abscission (photo by Rabbi Y.M. Lieberman).

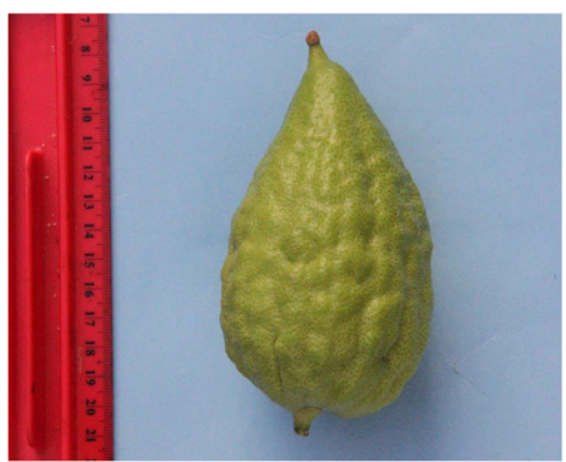

Fig. 5. A mature citron fruit cv. Ordang with a persistent style (photo by Y. Halperin).

tle; this seems to be the origin of the term "pistil" (Online Etymological Dictionary, Douglas Harper, 2010).] As the flower approaches anthesis, the stigma is ready to accept the pollen, which will germinate and cover the style length till the ovary, and to fertilize the ovules and produce seed. When anthesis comes to an end, gradual abscission of floral organs takes place, and then, after initial fruit set $(\approx 10-14 \mathrm{~d}$ after anthesis), the style and stigma abscise. The appearance of a light-brown ring, which marks the formation of an abscission layer in the middle of the

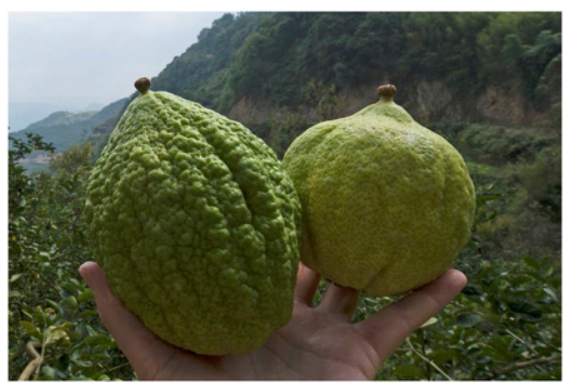

Fig. 6. A persistent style citron cultivar, centra Yunnan; persistent styles present in most but not all fruits of a tree (photo by David Karp).

style, precedes the actual drop (Goldschmidt and Leshem, 1971). This is the course of events in most citrus cultivars (Fig. 4), with the exception of certain citron cultivars in which the style and stigma do not abscise; they persist as a distal fruit organ throughout fruit development and maturation (Fig. 5). The persistent style, as it is called nowadays, has been called "pigolo" in Italian or "duesslein" in German (Volkamer, 1708) and "pitam" in Hebrew, following the Talmudic term ("pitma," Mishna Sukkah 3:6). Persistent styles are rare in some citron cultivars (e.g., 'Yemen') but occur frequently in others. Among the recently studied Chinese citrons, there is also a persistent style cultivar (Fig. 6). Persistent styles appear regularly in the bergamot (Citrus bergamia), which seems to be a citron hybrid (Nicolosi et al., 2000a), or, according to more recent studies, an indirect citron hybrid (Curk et al., 2016), and sometimes in Citrus limonimedica, another presumed citron hybrid (Pessina et al., 2011). The genetic-physiological basis of style persistence has not been investigated, but synthetic auxins, known to inhibit a range of abscission events (Taiz and Zeiger, 1998), are effective in this system as well and may promote style persistence. Experiments conducted in 'Valencia' orange, aimed to control fruitlet drop with the synthetic auxin herbicide Picloram (Cox, 1998), resulted in 


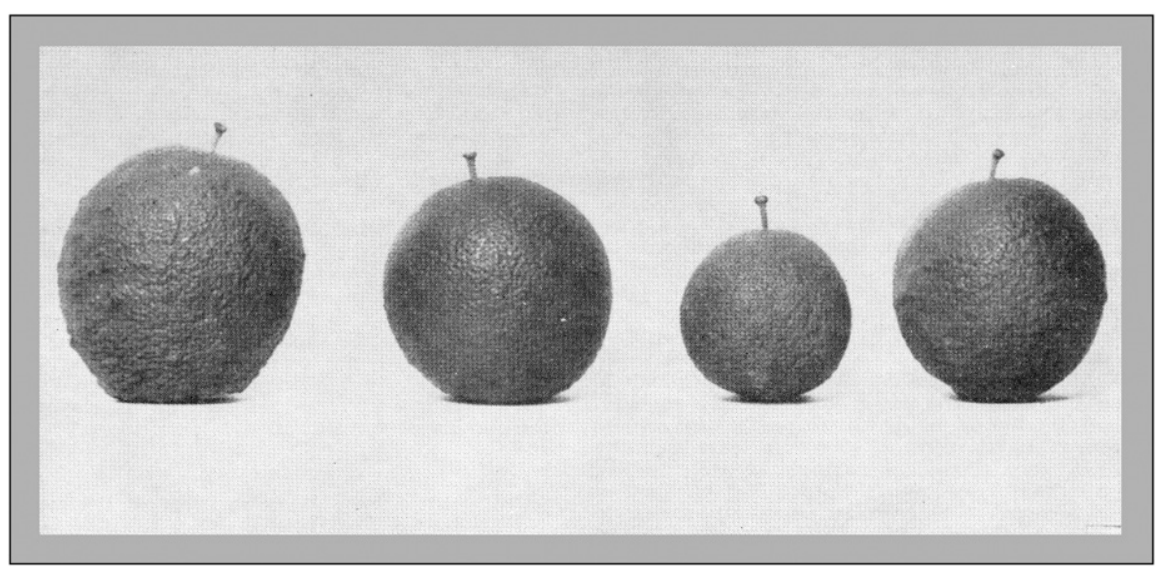

Fig. 7. 'Valencia' orange fruit with persistent styles, after a spray of Picloram (Goldschmidt and Leshem, 1971, by permission).

style persistence (Fig. 7; Goldschmidt and Leshem, 1971). This surprising finding indicated that this chemical might be useful in promoting style persistence in citrons. Indeed, following a few successful field experiments (Goldschmidt, 1970), Picloram was adopted by citron growers in Israel and elsewhere and is sprayed on citron trees during anthesis as a means to obtain the highly desirable, persistent style citrons.

But how critical is the presence of a persistent style for the citron to be fit (=kosher) for the traditional Tabernacles ceremony? This seemingly simple question does not have a straightforward answer. The relevant Talmudic paragraph (Mishna Sukkah 3:6) states "... removal of the pitma renders it (=the citron) unfit... but if the peduncle was removed it is still kosher..." There, is however, a difference of opinions among the Talmudic commentaries with regard to the term "pitma." Although some think that "pitma" is the persistent style (which is nowadays called "pitam"), others maintain that "pitma" is the innermost part of the peduncle. Thus, the requirement of a persistent style for a citron to be fit is controversial. There is nonetheless a general agreement among the Halachic authorities that natural drop of the style does not render the citron unfit.

At this point, one may wonder whether this controversy could be resolved by the numerous archaeological finds-mosaics, coins, and wall paintings - that depict citrons. But, regrettably, this kind of evidence is also equivocal. In most cases, citrons appear with a pointed head but no protruding, persistent style. There are a few cases where a persistent style is clearly evident (Fig. 8), but then, there are others with round-headed citrons that obviously do not have a persistent style (Fig. 9). However, a long, T-shaped peduncle is apparent in many cases (Nicolosi et al., 2005). The emerging impression is that citrons without a persistent style were quite common during the Roman and Byzantine era, and were acceptable for Tabernacles, but the presence of the peduncle has apparently been considered obligatory. During the Re-

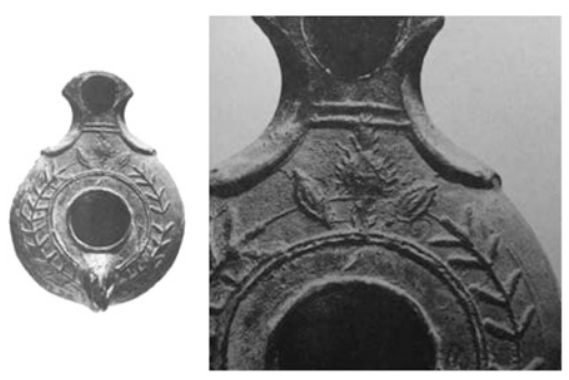

Fig. 8. Citrons with a persistent style on an ornamental Jewish oil lamp, Palestine, second century (from V. Sussman, Ornamental Jewish Oil Lamps, 1972, by permission).

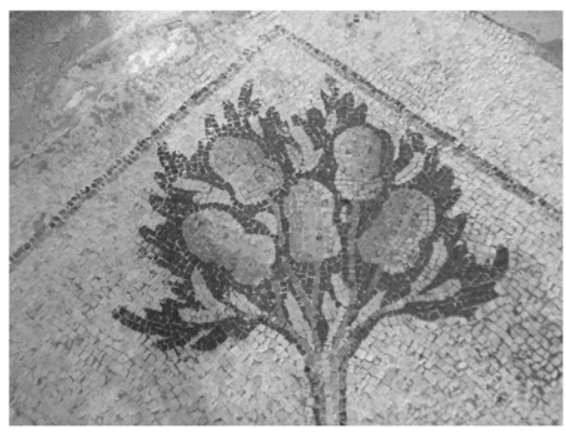

Fig. 9. A citron tree with fruit; "Birds Mosaic" in a Byzantine villa's courtyard, Caesarea Maritima, sixth century. Note the fruits' rounded tip without a persistent style (photo by Dr. Rivka Ben-Sasson).

naissance and subsequent centuries, citrus fruits, including citrons, were highly valued as exotic fruits, being grown in glass houses (orangeries) in Northern Italy and even further north. Ferrari (1646) contains several pictures of citrons, none of which has a persistent style. Volkamer's Nurenbergische Hesperides (1708) depicts many citron cultivars, only one of which has a complete persistent style (Fig. 10) and another which has a protruding style without a stigma (Fig. 11). Volkamer calls the persistent style citron (Fig. 10) "Der Juden Citronat Apffel" (=The Jews'

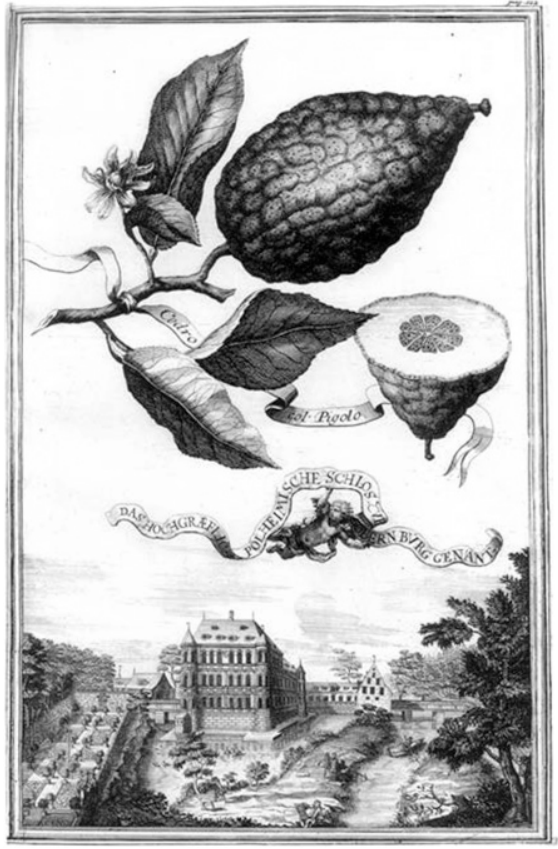

Fig. 10. Picture of a citron fruit with a persistent style (Cedro col Pigolo) from the Nürnbergische Hesperides of Volkamer (1708).

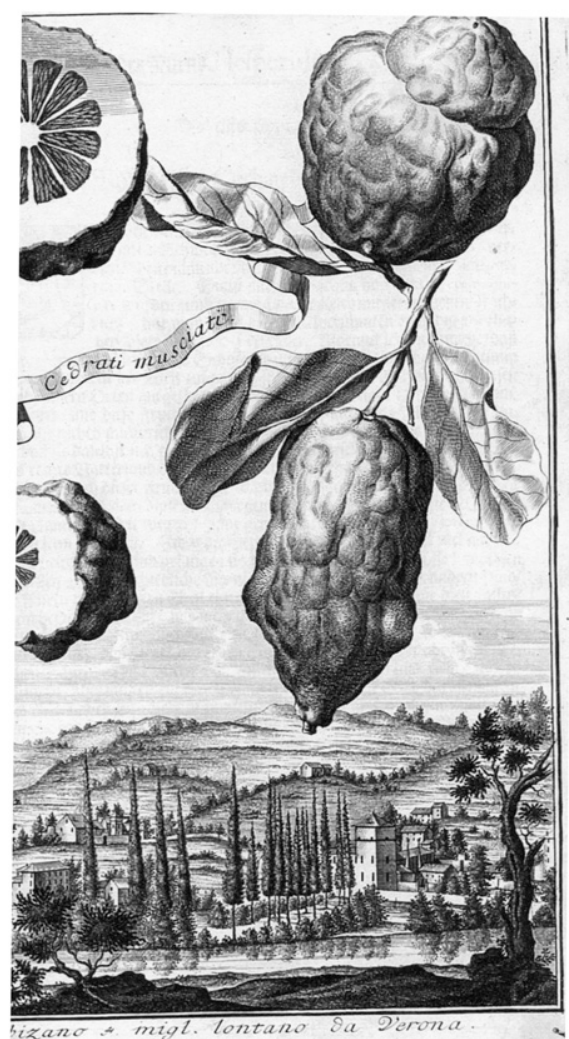

Fig. 11. Picture of a citron fruit with an incomplete persistent style (Cedrati musciati) from the Nürnbergische Hesperides of Volkamer (1708).

citron apple), indicating that Jews preferred citrons with a persistent style, although this is not an obligatory requirement. This notion is supported by the fact that cultivars with 
persistent styles, like the Corfu citrons (19th century) were in high demand by Jewish consumers (Amar, 2012; Sofer, 2015), even though they were very expensive.

\section{Concluding Remarks}

The present report complements and extends an earlier review of citron history and genetics (Nicolosi et al., 2005). Remarkable progress has been achieved during the last decade in the deciphering of citrus genomics and evolution, elucidating also some of the specific biological and molecular traits of Citrus medica. The inclusion of Chinese citron accessions in recent molecular analyses has raised questions regarding the evolutionary source of the fingered citron. The persistent style is a unique citron developmental phenomenon which has not received sufficient attention heretofore and was examined in the present article in considerable detail. A lot has been accomplished, and yet, the citron enquiry has not been exhausted; the citron still holds many secrets which wait to be investigated and disclosed.

\section{Literature Cited}

Amar, Z. 2012. Etrogim of the Land of Israel: A modern study of their roots, Tel Aviv. (Hebrew).

Barkley, N.A., M.L. Roose, R.R. Krueger, and C.T. Federici. 2006. Assessing genetic diversity and population structure in a citrus germplasm collection utilizing simple sequence repeat markers (SSRs). Theor. Appl. Genet. 112: 1519-1531.

Barrett, H.C. and A.M. Rhodes. 1976. A numerical taxonomic study of affinity relationships in cultivated Citrus and its close relatives. Syst. Bot. 1:105-136.

Carbonell-Caballero, J., R. Alonso, V. Ibañez, J. Terol, M. Talon, and J. Dopazo. 2015. The relationships between wild and domestic spe- cies withinthe genus Citrus. Mol. Biol. Evol. 32:2015-2035.

Cox, C. 1998. Picloram. J. Pestic. Reform 18:13-20.

Curk, F., F. Ollitraut, A. Garcia-Lor, F. Luro, L. Navarro, and P. Ollitraut. 2016. Phylogenetic origin of limes and lemons revealed by cytoplasmic and nuclear markers. Ann. Bot. (Lond.) 117:565-583.

Ferrari, G.B. 1646. Hesperides: Sive De Malorum aureorum cultura et usu libri quatuor. Hermanni Scheus, Rome.

Goldschmidt, E.E. 1970. Prospects of preventing citron (Citrus medica L.) style abscission by spraying Picloram. Hasadeh 50:740-742. (Hebrew).

Goldschmidt, E.E. 1976. Factors determining the shape of citrons. Isr. J. Bot. 25:34-40.

Goldschmidt, E.E. 2009. Citron propagation: Seeds or cuttings? Alon Hanotea 63:44-46. (Hebrew)

Goldschmidt, E.E. and B. Leshem. 1971. Style abscission in the citron (Citrus medica L.) and other Citrus species: Morphology, physiology and chemical control with Picloram. Amer. J. Bot. 58:14-23.

Hodgson, R.W. 1967. Horticultural varieties of citrus, p. 431-591. In: W. Reuther, H.J. Webber, and L.D. Batchelor (eds.). The Citrus Industry, vol. I. Univ. of California Press, Berkeley, CA.

Isaac, E. 1959. Influence of religion on the spread of citrus. Science 129:179-186.

Jena, S.N., S. Kumar, and N.K. Nair. 2009. Molecular phylogeny in Indian Citrus L. (Rutaceae) inferred through PCR-RFLP and trnL$\operatorname{trnF}$ sequence data of chloroplast DNA. Sci. Hort. 119:403-416.

Karp, D. and X. Hu.The citron (Citrus medica L.) in China. The Etrog Citron (Citrus medica L.). Tradition and Science (in press).

Langgut, D.The Citrus route revealed: From Southeast Asia into the Mediterranean. HortScience (in press).

Luro, F., N. Venturini, G. Costantino, J. Paolini, P. Ollitrault, and J. Costa. 2012. Genetic and chemical diversity of citron (Citrus medica L.) based on nuclear and cytoplasmic markers and leaf essential oil composition. Phytochemistry 77:186-196.

Maruca, G., G. Laghetti, and K. Hammer. 2015. Religious and cultural significance of the citron
Citrus medica L. ('Diamante') from Calabria (South Italy): A Biblical Fruit of the Mediterranean Land. Journal of Environmental Science and Engineering A 4:203-209.

Nicolosi, E., Z.N. Deng, A. Gentile, S. La Malfa, G. Continella, and A. Tribulato. 2000a. Citrus phylogeny and genetic origin of important species as investigated by molecular markers. Theor. Appl. Genet. 100:1155-1166.

Nicolosi, E., S. La Malfa, and E.E. Goldschmidt. 2000b. Molecular analysis of the phylogenetic relationships of 12 citron accessions. Proc. Intl. Soc. Citricult. p. 183.

Nicolosi, E., S. La Malfa, M. El-Otmani, M. Negbi, and E.E. Goldschmidt. 2005. The search for the authentic citron (Citrus medica L.): Historic and genetic analysis. HortScience 40:1963-1968.

Pessina, D., R. Gentili, G. Barcaccia, S. Nicole, G. Rossi, S. Barbesti, and S. Sgorbati. 2011. DNA content, morphometric and molecular marker analyses of Citruslimonimedica, $C$. limon and C. medica for the determination of their variability andgenetic relationships within the genus Citrus. Sci. Hort. 129:663-673.

Ramadugu, C., M.L. Keremane, X. Hu, D. Karp, C.T. Federici, T. Kahn, M.L. Roose, and R.F. Lee. 2015. Genetic analysis of citron (Citrus medica L.) using simple sequence repeats and single nucleotide polymorphisms. Sci. Hort. 195:124-137.

Scora, R.W. 1975. On the history and origin of Citrus. Bull. Torrey Bot. Club 102:369-375.

Sofer, L.Y. 2015. Purity of the citrons. Hamachon, Brooklyn, NY. (Hebrew).

Taiz, L. and E. Zeiger. 1998. Plant physiology. 2nd ed. Sinauer Associates, Sunderland, MA.

Tolkowsky, S. 1938. Hesperides. A history of the culture and use of citrus fruits. John Bale, Sons and Curnow, London.

Volkamer, J.C. 1708. Nürnbergische Hesperides, Oder Gründliche Beschreibung Der Edlen Citronat, Citronen und Pomerantzen-Früchte. Nuernberg, vol. 2.

Yang, X., L. Hang, M. Liang, Q. Xu, L. Chai, and X. Deng. 2015. Genetic diversity and phylogenetic relationships of citron (Citrus medica L.) and its relatives in southwest China. Tree Genet. Genomes 11:129, doi: 10.1007/s11295-015-0955-x. 